\title{
Direction of Changes on the Milk Markets in Poland, the Czech Republic and Slovakia in Comparison with the Biggest Milk Producers in EU (2005-2016)
}

\author{
Anna OLSZAŃSKA ${ }^{1}$, Jaroslava DITTRICHOVÁ ${ }^{2}$ \\ ${ }^{1}$ Wrocław University of Economics, Wrocław, Poland \\ anna.olszanska@ue.wroc.pl \\ ${ }^{2}$ University of Hradec Králové, Hradec Králové, Czech Republic \\ jaroslava.dittrichova@uhk.cz
}

\begin{abstract}
Milk production is one of the main items in livestock production and more broadly in agricultural production. It is characterized by specific economic and organizational characteristics. The aim of the study is to determine the changes in the purchase and sale prices of milk in three selected countries, which joined the European Union in 2004 in Poland, the Czech Republic and Slovakia in comparison with the largest milk producers in the European Union. In particular, the subject of the study was an analysis of trends of changes, seasonal cyclical fluctuations for purchase prices and the volume of milk purchased in the analyzed countries. In the paper a multiplicative model of time series analysis was used. The analyzed data covered the years 2005-2016.
\end{abstract}

Keywords: Milk Market, Production, Seasonal Variation.

\section{Introduction}

Milk production is one of the main items in livestock production and more broadly in agricultural production. It is characterized by specific economic and organizational characteristics. In particular, it is distinguished from other agricultural activities by high labor intensity and capital intensity, a strong link between milk production and plant production on the farm, difficult to obtain, the desired hygienic quality of milk and the necessity of cooperation between the producer and the processing plant. The condition for the development of production is that these traits are compensated for by the price of the product or subsidies to the farmers involved in the production of milk. [13] Owing to the above mentioned characteristics, changes in the structure of production on the farm usually require time, with the greatest influence on the decisions made are the profitability of the production and the possibility of selling the products [7].

The market for agricultural raw materials operates in line with market economy principles but is characterized by higher volatility than other markets. The prices, according to the law of demand and supply, act as regulators of market processes 
[12]. The supply situation in this market was influenced by the milk quota resulting from the CAP, which was finally lifted in 2015/2016.

In previous years, the amount of milk quotas for the following marketing years was determined by Council Regulation (EC) $[1,11]$. Under these regulations, the national amounts were increased by $1 \%$ in subsequent quota years up to the 2013/2014 quota year. From the year 2004/2005 until the end of the milk quotas period, the milk quota for the newly admitted countries grew slightly more than for the majority of the so called "Old members" and for the Czech Republic this increase was 9.4\%, Poland $12.2 \%$, Slovakia - 10.1\% and Germany and France - 8.8\%, [10].

Following the expiry of milk production quotas by the end of 2015, the European Commission decided to solve a possible imbalance between the supply and demand of milk aimed at reducing milk production in 2016 and 2017. Its aim was to maximize the drop in milk prices that could have been caused by its increased production. The European Commission earmarked EUR 150 million for this scheme. This amount reduced a milk production in the European Union of approximately 1.07 million tonnes. The amount of aid per $100 \mathrm{~kg}$ of milk, which is not delivered to the market, was 14 euros [5]. From November 2016 to January 2017, 48288 milk producers reached a total production reduction of 860907 tonnes of milk. [2]

This scheme caused stop decreasing trend of purchase price of milk and, together with rising demand, started increasing trend of its prices from EUR 29/100 kg in 2016 to EUR 35/100 kg in 2017. [3, 9]

The milk market (supply and demand) is constantly expanding and increasing. However, the increasing milk production in the EU is due not only to the end of quota in 2015 but also to increasingly popular automated milking systems for cows. [14]. For example, in Latvia during the last ten years farms involved in commercial milk production often had substantial modernization, the farmers are motivated to improve cows keeping and feeding. Thereby average milk yield per cow during the ten years has increased by $42 \%$ and the average milk price in has increased by $60 \%$ with variation during the seasons. [8] The growing demand is related, among other things, to a change in consumer behaviour caused by change in the social and economic factors affecting individual demand for milk [4]. Market of milk is a highly regulated market, which limited the increase in production and the possibility of exploiting the competitive advantages of individual countries.

\section{$2 \quad$ Methods and sources of materials}

The aim of the study is to determine the changes in the purchase and sale prices of milk in three selected countries, which joined the European Union in 2004 in Poland, the Czech Republic and Slovakia in comparison with the largest milk producers in the European Union. In particular, the subject of the study was an analysis of trends of changes, seasonal cyclical fluctuations for purchase prices and the volume of milk purchased in the analyzed countries.

In the paper a multiplicative model of time series analysis was used. The analyzed data covered the years 2005-2016. The study was mainly based on statistical data from Eurostat. Analysis was based on monthly data. 


\section{Results and discussion}

The main producer of milk in the European Union is Germany. Their share in the years 2005-2016 was 20-21\%. France had slightly lower and at the same time much more fluctuating share (16-20\%). The United Kingdom was also the leading milk producer in the Union. In fourth place, but with a variable share not exceeding $9 \%$ was Poland. The Czech Republic share of milk production in the Union was quite stable and did not exceed $2 \%$. Slovakia was in a distant position, with a declining share of about $1 \%$ of EU production to around $0.6 \%$ at the end of the analysis period. In Germany, France and Poland, the buying volume was characterized by a distinct upward trend, with the highest increase in Poland (by 26.2\% in 2016 compared to 2005) (fig.1.2). In the Czech Republic there was a slight increase in purchases, but it was noted that apart from the last year of the analyzed period, the volume of purchases was lower in all years than in 2005. Of the analyzed countries only Slovakia had a negative trend in milk purchase volume, per year, on average of 13 thousand tonnes per year. As a result, in 2016, the purchase of raw milk for processing accounted for $85 \%$ of the purchase volume in 2005.

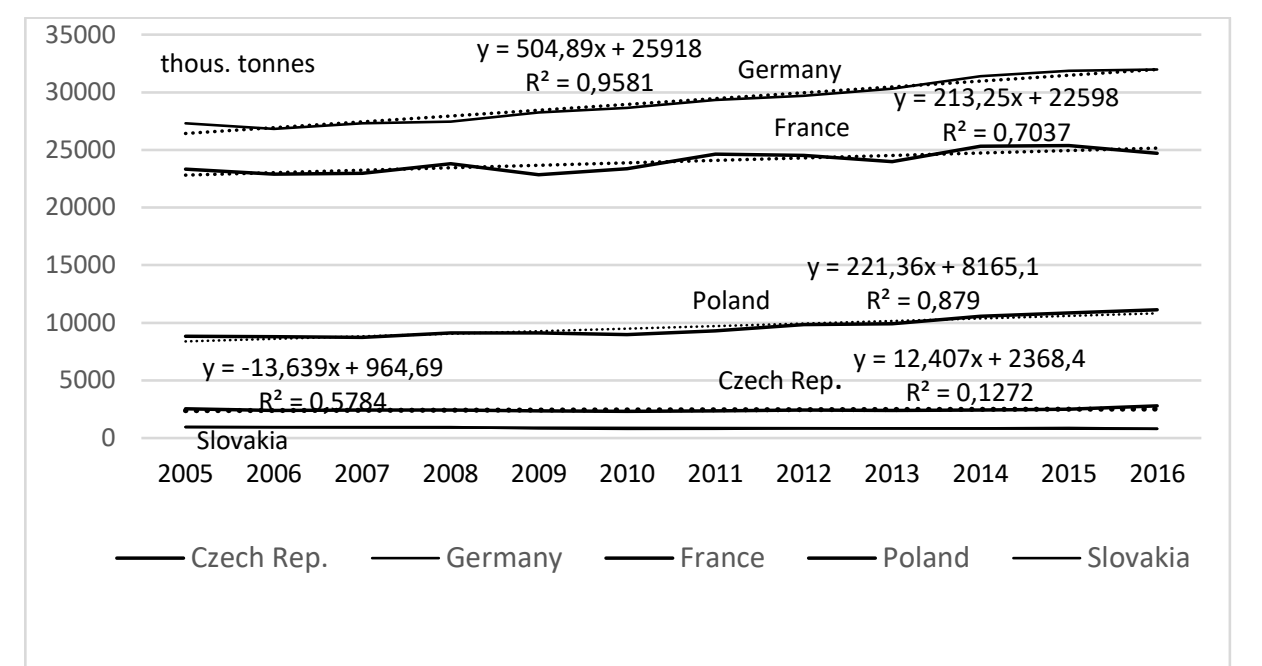

Fig. 1. Purchase of milk in selected countries in EU in 2005-2016 (thousand tonnes). $[3,10]$ 


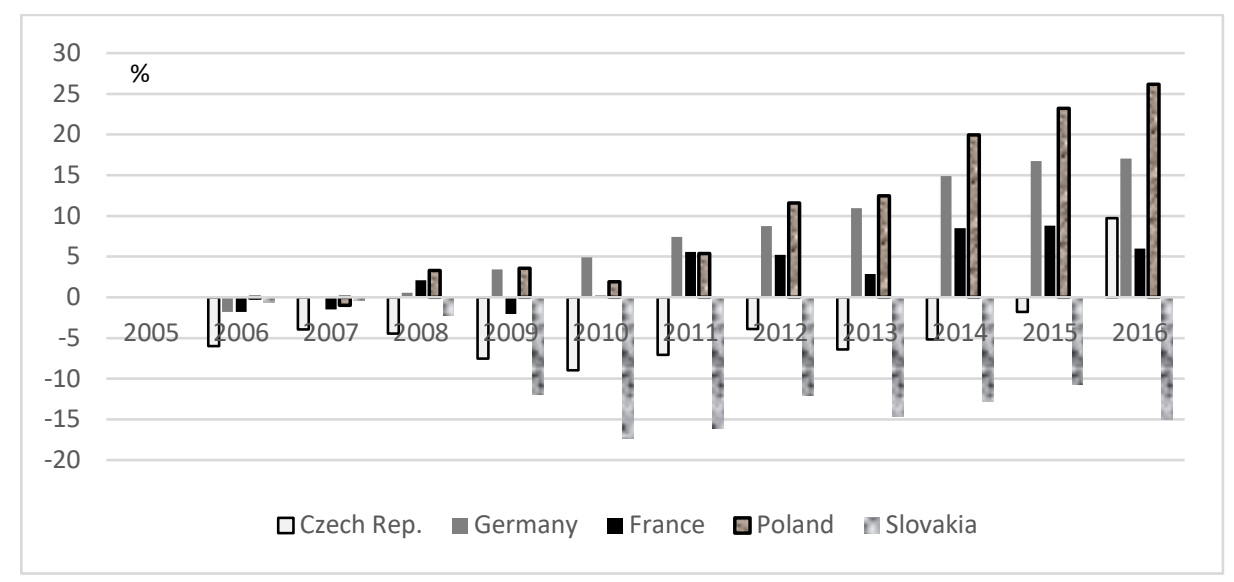

Fig. 2. Dynamics of changes in the volume of milk purchase in selected countries in EU in $2005-2016(2005=100 \%)$. [3,10]

Data analysis showed that there were no significant cyclical fluctuations in the purchase volume. A bit more variation of this type took place only on the French market. However seasonal fluctuations in the market are characteristic for this market. They are associated, to a large extent, with seasonal calving (periods of cows' reproduction), climatic conditions (diet change during spring and summer), herd level for multiple dairy farms and cow parity [6] (fig 3).

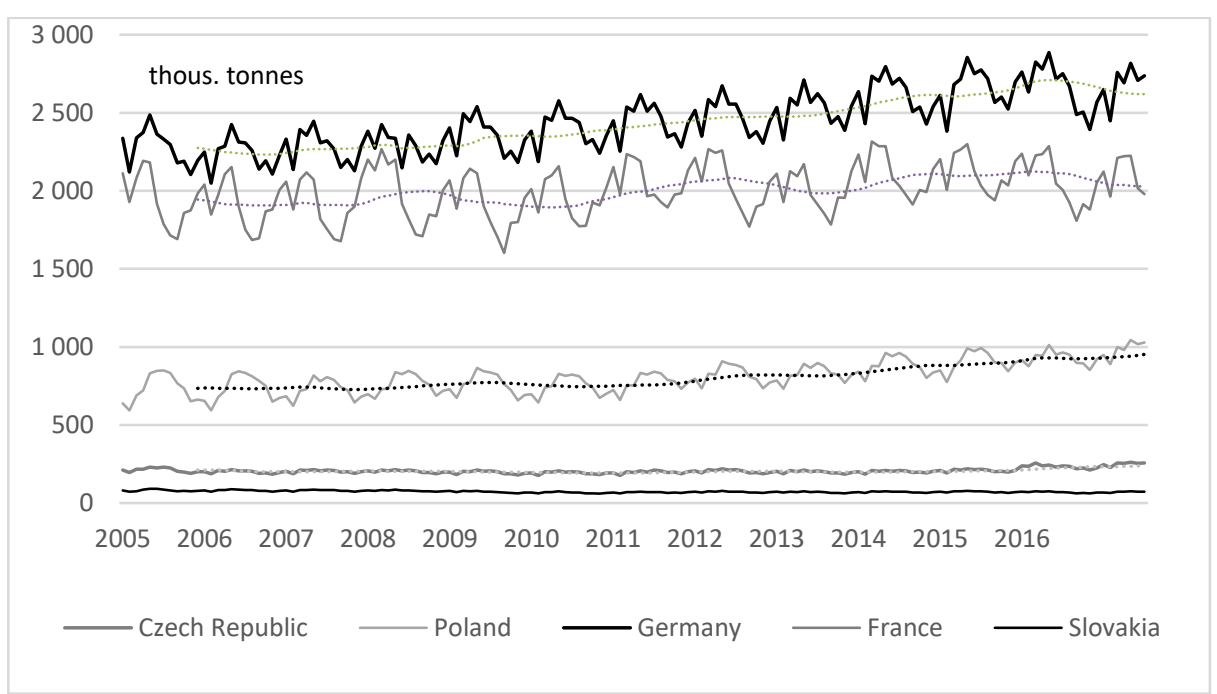

Fig. 3. Monthly milk volume changes in selected EU countries in 2005-2016 (thousand tonnes). [3]

Fig. 4 shows the average seasonality indexes for individual months for the whole 2005-2016 period. The obtained results indicate that in the analyzed countries the 
distribution of the volume of purchases per year was similar. In most countries purchase volume above the monthly average was noted from March to August. In most countries, except Poland, higher than average purchases were also in January. In the remaining months of the year, to different extent, purchases were lower than the average. The scale of fluctuations in purchase volume in particular months of the year was usually in the range of $+/-10 \%$. Higher fluctuations in particular months were recorded in Poland and France. Seasonality in the purchase of milk is a normal phenomenon, processing plants are prepared for these fluctuations. However, the smaller they are, the better the processing plants can function. There is no problem with periodic failures or excess of raw material, there is no need to create excessive stocks of finished products in the form of eg powdered milk.

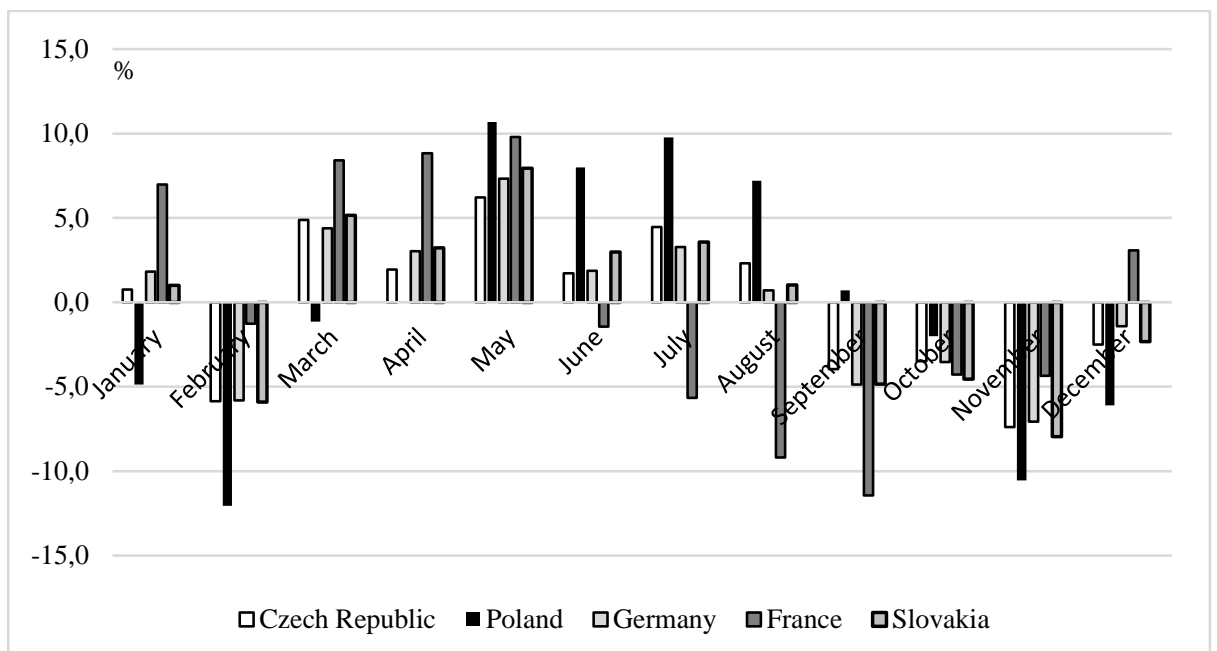

Fig. 4. Seasonal variation in milk purchase volume in particular months of the year in selected EU countries (2005-2016 average,\%). [3]

The average seasonality values calculated for the following years show differences in variation between countries (fig. 5). (Due to the construction of this indicator and the lack of data on the purchase in 2004, it was not possible to calculate it for 2005). In most of the analyzed years, the purchases in Poland and France were slightly more volatile, with the value of these coefficients decreasing in the following years. Stable diversification in annual sales, at the level of about $4 \%$, occurred in subsequent years in Germany. In the subsequent years, the seasonal increase of the milk purchase in the Czech Republic increased slightly from below $4 \%$ in 2006-2014 to around 5\% in the years 2015-2016. 


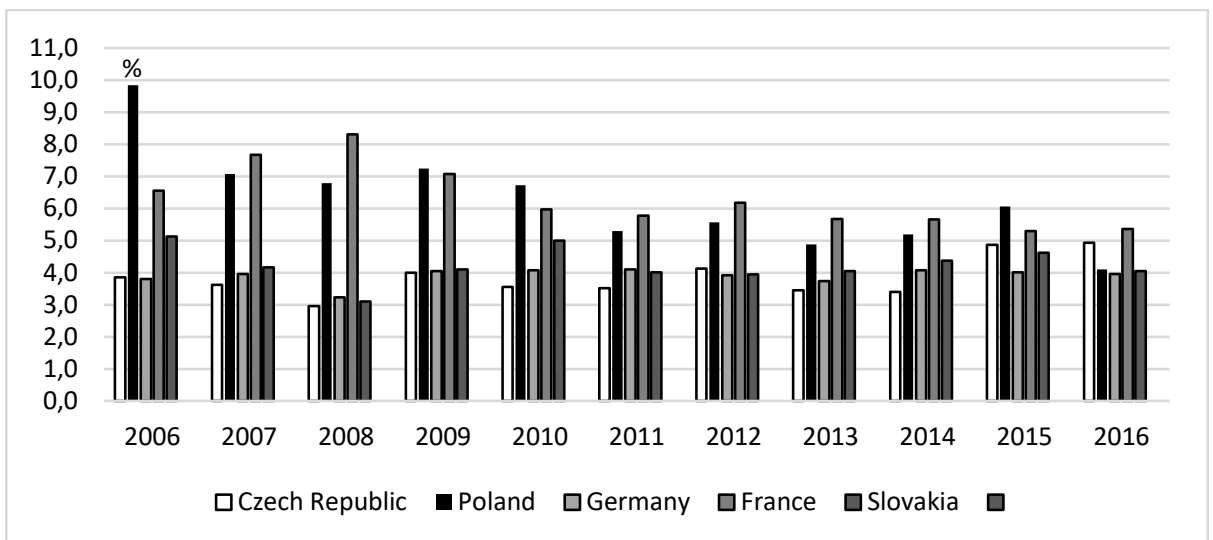

Fig. 5. Seasonality coefficients of milk purchase volume for particular years 2005$2016(\%)$. [3]

Compared to relatively small changes in the volume of milk purchased in subsequent years, significant price fluctuations were observed (fig. 6). However, in each month there was a clear tendency for them to be leveled between the analyzed countries. In the most analyzed months, prices for milk producers were favorable in Germany and France and the least favorable in Poland. This was true of both high and low prices. By mid-2007, ie in the first years after the enlargement of the Union, milk prices fluctuated to a relatively small extent. Very large price increases in all analyzed countries took place in the second half of 2007. After a short period of price hikes, they fell sharply to EUR 20-25 / $100 \mathrm{~kg}$. For example, in Germany, the average monthly purchase price for October-December 2007 was around $€ 41 / 100 \mathrm{~kg}$, and in July-September 2009 it was around $€ 22 / 100 \mathrm{~kg}$. After this period the milk market was very unstable in the months following, despite the regulations in force in this market.

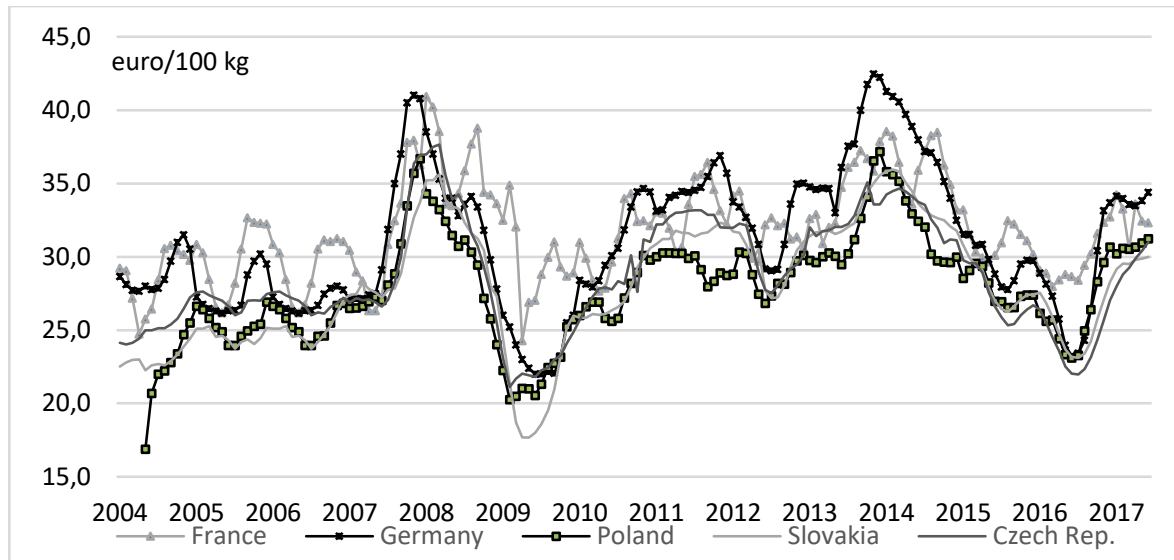

Fig. 6. Monthly milk purchase prices in selected EU countries for 2005-2016 (\%). [3, 9] 


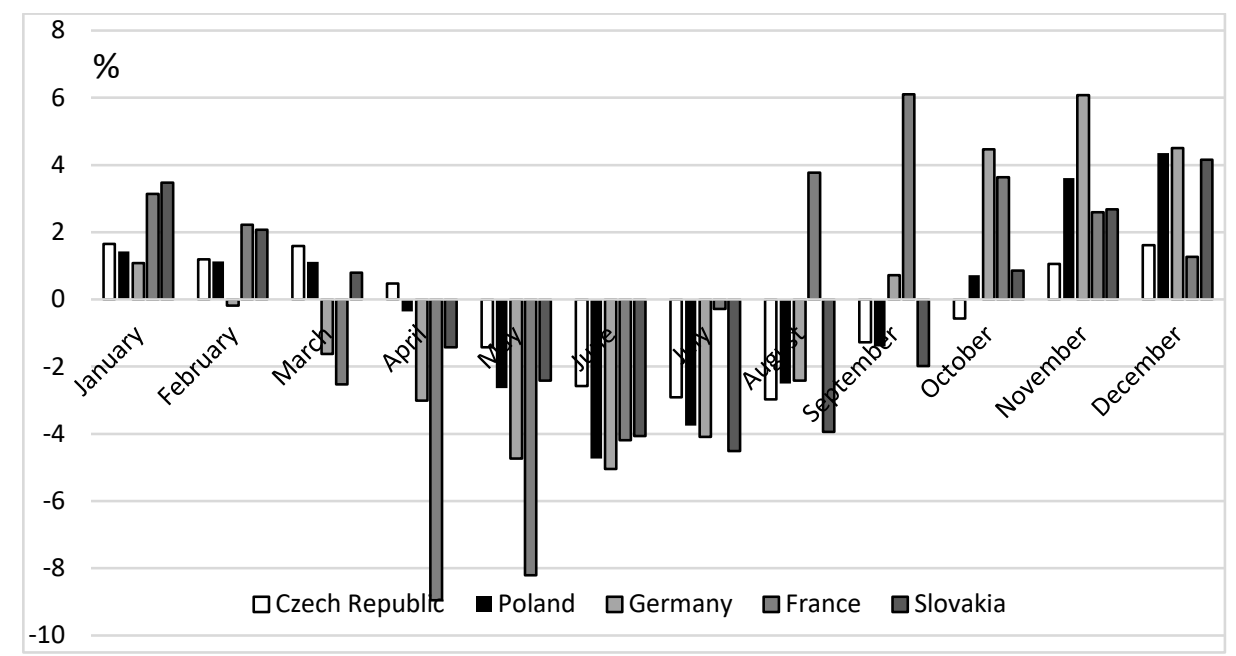

Fig. 7. Seasonality of milk purchase price changes in individual months of the year in selected EU countries (2005-2016 average,\%). [3, 9]

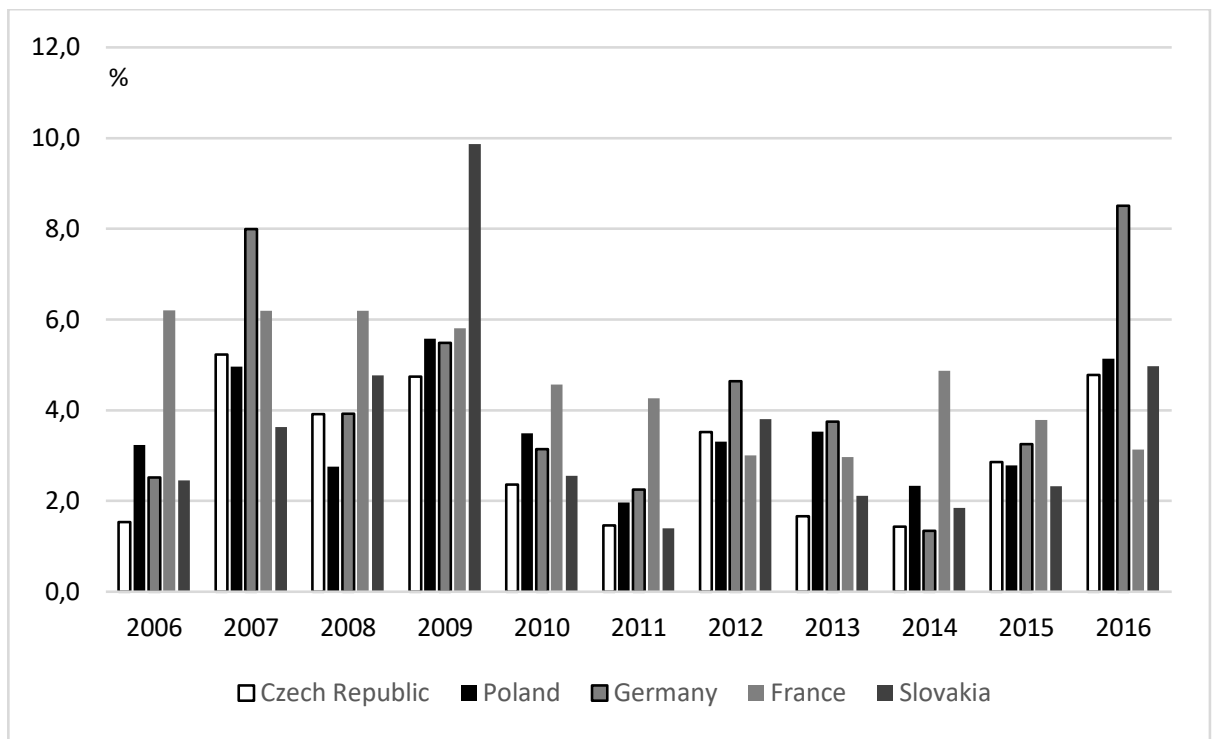

Fig. 8. Seasonality coefficients of milk purchase prices for individual years 2005$2016(\%) .[3,9]$

The data on average seasonality indexes of buying and selling prices by month in the analyzed countries allow us to formulate a number of detailed conclusions (in order to facilitate comparisons, all figures are used in the same scale) (fig. 9). 


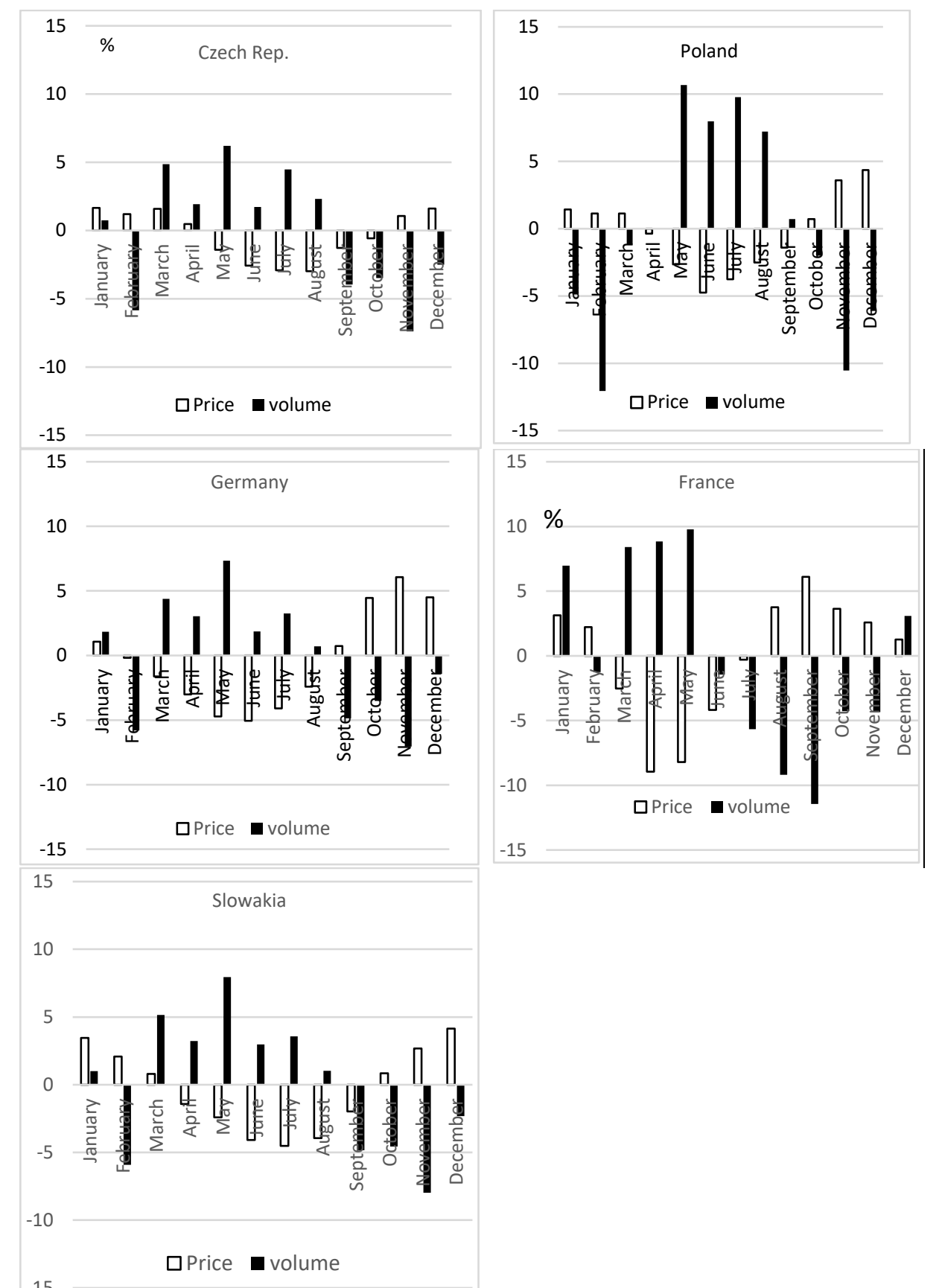

Fig. 9. Average seasonality coefficients of milk and milk seasonality in individual countries in 2005-2016 (\%). [3, 9, 10] 
- In all countries there were close links between buying prices and buying volumes. This demonstrates the regularity of the changes in the scale of the year and the rapid reactions of the market to changes in raw material supply.

- In each of the countries surveyed, seasonality rates for purchase prices for individual months are generally lower than the corresponding purchasing rates. This is probably the result of regulations in force in most of the analyzed years.

- Based on the fluctuations, these countries can be divided into two groups. Milk markets in the Czech Republic, Germany and Slovakia were more stable compared to the Polish and French markets.

- Seasonal changes in the French market are different from those in the other analyzed countries.

\section{Conclusions}

The milk market in the EU is a specific market due to its existing conditions resulting from the Common Agricultural Policy. The supply situation in this market was influenced by the quotation of its output, which was finally lifted in 2015/2016.

The main milk producers in the EU are Germany, France and the United Kingdom. Poland was in fourth position in the analyzed years but its shares were much lower than Germany's and did not exceed 9\%. The shares of the Czech Republic and Slovakia were much smaller. Germany, France and Poland's share in total milk production in the EU increased, while in the Czech Republic and Slovakia they were characterized by stagnation or decline.

The milk market is characterized by seasonal fluctuations in the volume of purchases in particular months of the year. In most of the countries analyzed, the distribution of annual sales was similar. Significant differences were observed in France. More important differences occurred in the case of the scale of these fluctuations. Larger scale fluctuations were observed in Poland and France, but in subsequent years there was a tendency to decrease their scale. In the Czech Republic, there was a slight uptick in the subsequent years to increase the diversification of buying in the coming months. The most stable and predictable fluctuations occurred throughout the analyzed period on the German market.

Compared to the relatively small changes in the monthly milk purchase volume in the following analyzed years there were significant fluctuations in the price of its purchase. At the same time there was a tendency to level the price between individual countries. In most of the analyzed months, prices were slightly higher for milk producers in Germany and France. However, significant price changes in subsequent years are not favorable for both milk producers and processors, and may favor decisions to withdraw producers from this direction.

By analyzing the average values of the seasonality coefficients of purchase prices compared to the corresponding indexes for the volume of purchases, it can be concluded that in the case of buying volume in most analyzed countries there was a slight tendency to decrease them in subsequent years. The average values of seasonality coefficients of purchase prices of the analyzed countries significantly 
decreased between 2010 and 2015. In 2016, there was a resurgence of their size in most of the analyzed countries, except for France.

\section{References}

1. Council of the European Union: [nr 72/2009 z 19 stycznia 2009 r. w sprawie zmian we wspólnej polityce rolnej poprzez zmianę rozporządzeń (WE) nr 247/2006, (WE) nr 320/2006, (WE) nr 1405/2006, (WE) nr 1234/2007, (WE) nr 3/2008, (WE) nr 479/2008].

2. EU scheme helps reducing milk production, https://ec.europa.eu/info/news/eu-schemehelps-reducing-milk-production-2017-apr-06_en, last accessed 2017/11/03.

3. http://ec.europa.eu/eurostat/data/database, last accessed 2017/10/10.

4. Kapaj, A., Deci, E.: World Milk Production and Socio-Economic Factors Effecting Its Consumption. Dairy in Human Health and Disease Across the Lifespan, 107-115 (2017). doi:10.1016/b978-0-12-809868-4.00007-8.

5. Milk Production Reduction Scheme - 2016 - "July Package", https://ec.europa.eu/agriculture/sites/agriculture/files/milk/policy-instruments/exceptionalmeasures-aid-production-reduction_en.pdf, last accessed 2017/11/03.

6. Murphy, M., O'Mahony, M., Shalloo, L., French, P., Upton, J.: Comparison of modelling techniques for milk-production forecasting. Journal of Dairy Science, 97(6), 3352-3363 (2014). DOI:10.3168/jds.2013-7451.

7. Olszańska, A.: Rynek żywca wieprzowego w Unii Europejskiej w latach 1990-2015 analiza zmian na przykładzie wybranych państw. Roczniki Naukowe SERiA, vol. XVIII, z.3, pp.279-284 (2016).

8. Paura, L., Arhipova, I.: Analysis of the Milk Production and Milk Price in Latvia. Procedia Economics and Finance, 39, 39-43 (2016), doi:10.1016/s2212-5671(16)30238-6.

9. Rynek mleka, http://www.minrol.gov.pl/ last accessed 2017/10/10.

10. Rynek Mleka. Stan i Perspektywy, IERiGŻ-PIB, ARR, MRiRW, 2001-2016.

11. Seremak-Bulge, J., Dybowski, G., Pasińsk,a D., Roman, M., Zawadzka, D., Stańko, S.: Sytuacja na światowych rynkach mięsa i produktów mleczarskich oraz jej wpływ na rynek krajowy i możliwości jego rozwoju. IERiGŻ - PIB, Warszawa (2016).

12. Śmigła, M.: Ekonomiczne determinanty produkcji mleka w makroregionach Unii Europejskiej. Rozprawa doktorska. Uniwersytet Ekonomiczny w Poznaniu, Poznań (2015), http://www.wbc.poznan.pl/Content/351856/Smigla_Marta_doktorat.pdf, last accessed 2017/10/10.

13. Stańko, S.: Zmiany i projekcje rozwoju na podstawowych rynkach rolnych w Polsce. SGGW, Warszawa (2013).

14. Tremblay, M., Hess, J. P., Christenson M. B, McIntyre, K. K., Smink, B., Kamp, van der Arjen, J.,de Jong, L. G., Döpfer, D.: Factors associated with increased milk production for automatic milking systems. Journal of Dairy Science 99(5), 3824-3837 (2017), DOI: 10.3168/jds.2015-10152. 